\title{
Evaluating Financial Viability of Olive Mills Enterprise in Jordan
}

\author{
Bassam Aldeseit ${ }^{1}$ \\ ${ }^{1}$ Department of Agricultural Economics and Extension, Faculty of Agriculture, Jerash University, P.O. Box 311, \\ Jerash, Jordan \\ Correspondence: Bassam Aldeseit, Department of Agricultural Economics and Extension, Faculty of Agriculture, \\ Jerash University, P.O. Box 311, Jerash 26150, Jordan. E-mail: bkhitan2@yahoo.com
}

Received: October 8, 2013 Accepted: December 10, 2013 Online Published: March 15, 2014

doi:10.5539/jas.v6n4p173 URL: http://dx.doi.org/10.5539/jas.v6n4p173

\begin{abstract}
The main aim of this study was to evaluate financial viability of olive oil mills enterprise. Thirty olive mills were investigated. A questionnaire was designed to obtain information from mills owners. The information obtained was mainly related to costs and returns. Cash flows were derived from costs and returns items of the enterprise. Three main discounted measures of project worth were used; these were Net Present Value (NPV), the Internal Rate of Return (IRR), and the Benefit Cost Ratio (B/C). The results of this study revealed that olive mills could be a viable encouraging, and profitable enterprise because of its capability to generate a highly positive and acceptable NPV (837966.05 JDs). The IRR (85\%) and B/C ratio (2.3) values for this enterprise were economically accepted.
\end{abstract}

Keywords: olive mills, Net Present Value (NPV), Internal Rate of Return (IRR), Benefit to Cost Ratio (B/C)

\section{Introduction}

The importance of olive mills enterprise has developed significantly in Jordan in the last two decades. One of the most important fruit trees grown in Jordan is the olive tree. Olive production is a significant land use in Jordan. Nearly $72 \%$ of the fruit trees area and $36 \%$ the total cultivated area are planted with olive tree (Al-Shdiefat et al., 2007). The total production of olives in Jordan in the year 2012 was nearly 134000 tons. Around 100000 tons of the total production of olives were used to extract olive oil, from which 27500 tons of olive oil were extracted (Ministry of Agriculture or MOA, 2012). The olive trees planted in Jordan are used to make table olives as well as oil. The western mountain rain-fed area and the north-eastern irrigated desert region are the two main olive producing regions in Jordan.

In recent years, several Jordanian olive oil companies and olive products related companies formed the Jordanian Olive Products Exporters Association (JOPEA) to help in promoting olive oil production.

The association represents table olive producers, bottlers, and olive mills. Due to the increasing importance of olive mills enterprise in Jordan, this study is an attempt to investigate the economic feasibility of this enterprise. To achieve the objectives of this study cash flow analysis procedure was followed.

Three main reliable discounted financial indicators were used; The Net Present Value (NPV), the Internal Rate of Return (IRR), and the Benefit Cost Ratio (B/C). The Net Present Value or (NPV) considered being the result of subtracting the value of the initial investment from Present value of future net cash flows. If the value of NPV is positive the investment is to be made otherwise, it should not (Lin et al., 2000).

The IRR is an important indicator for any investment that gives a value to judge the investment (Bruce, 2003).

Baker (2000) indicated that if the value of the NPV is zero the discount rate at that value is the IRR of that investment. Accordingly, the IRR is the discount rate that generates a zero NPV. The IRR makes the sum of the PV (Present Value) of future CF (Cash Flows) equal to its current market value. At this point if the costs are higher than the IRR, it is advised to avoid the investment. Although the Benefits to Costs Analysis (BCA) approach is used mainly to investigate the feasibility of public investments, this approach is widely used in judging the economic viability of private enterprises (Orth et al., 1998). Bent et al. (2002) wrote that in any economic investment, the decisions could be analyzed using BCA. The main idea in CBA is the subtraction of costs from benefits (Boardman et al., 2001).

This study attempts to provide information on the economic viability of olive oil mills enterprise. 


\section{Olive Oil Industry in Jordan; Brief Review}

In the year 2001, Jordan was considered the tenth olive producing country in the world. There are nearly 17 million olive trees in Jordan, generating around $100 \mathrm{JD}$ million yearly incomes (MOA, 2012). The highest production of olive oil in the country was in the northern governorates of Irbid, Jerash, and Ajloun. Small and medium-size holders in these governorates were with the large number of olive farms. The olive mills enterprise is largely related and dependable on olive production. Due to the increase of olive production in Jordan, olive mills enterprise has largely expanded and developed in recent years. Around 27500 tons of olive oil were produced in the year 2012 through 122 olive mills with an average capacity of 3692 tons/hour. The country self-sufficiency ratio from olive oil in the same year (2012) was estimated to be $104.3 \%$. The Manufacturing Process of olive oil includes Collecting and grading the olives, washing and milling the olives, creating an olive paste, pressing the olive paste to extract the oil, separating the oil from the vegetable water, and storing and packaging the oil.

Table 1. Quantities of olives produced in Jordan during the period 2005 - 2011

Source: MOA, 2012.

\begin{tabular}{cc}
\hline Year & Olive Quantities (Tons) \\
\hline 2005 & 142078 \\
2006 & 243531 \\
2007 & 163904 \\
2008 & 138689 \\
2009 & 221588 \\
2010 & 171036 \\
2011 & 131800 \\
\hline
\end{tabular}

Table 2. Quantities of olive oil produced in Jordan during the period 2005 - 2011

\begin{tabular}{cc}
\hline Year & Olive Oil Quantities (Tons) \\
\hline 2005 & 20267 \\
2006 & 37156 \\
2007 & 24085 \\
2008 & 18472 \\
2009 & 36652 \\
2010 & 27311 \\
2011 & 27584 \\
\hline
\end{tabular}

Source: MOA, 2012.

Table 3. Total number of olive mills in Jordan according to governorates

\begin{tabular}{cc}
\hline Governorate & Number of Olive Oil Mills \\
\hline Amman & 10 \\
Irbid & 46 \\
Madaba & 3 \\
Zarqa & 6 \\
Jerash & 13 \\
Ajloun & 12 \\
Mafraq & 11 \\
Balqa & 9 \\
Karak & 4 \\
Tafeeleh & 2 \\
Maan & 3 \\
Aqaba & 1 \\
Total & 122 \\
\hline
\end{tabular}

Source: MOA, 2012. 
Table 1 shows quantities of olives produced in Jordan during the period 2005-2011 while Table 2 shows quantities of olive oil produced during the same period. Table 3 shows the total number of olive mills according to the country governorates.

\section{Materials and Methods}

Cash flow analysis methodology was used in this study. A 10-year cash flow data were utilized in the analysis process. Comparison of costs and returns was made. The average financial costs and returns evaluation uses the cost-benefit analysis (CBA) approach, which includes several measurements from the enterprise using NPV, IRR, and $\mathrm{BC}$ ratio financial tools.

\subsection{Sample}

A sample survey of 30 operating olive mills was conducted. The sample size was determined to be $25 \%$ of the total olive mills in the country. The distribution of the sample among the country was based on the number of mills in each governorate. Table 4 shows the distribution of the sample according to the country governorates.

Table 4. Distribution of the sample according to the country governorates

\begin{tabular}{cccc}
\hline Governorate & Number of Olive Oil Mills & \% in the sample & Number in the sample \\
\hline Amman & 10 & 8 & 2 \\
Irbid & 46 & 38 & 11 \\
Madaba & 3 & 2 & 1 \\
Zarqa & 6 & 4 & 1 \\
Jerash & 15 & 12 & 4 \\
Ajloun & 12 & 11 & 3 \\
Mafraq & 11 & 10 & 3 \\
Balqa & 9 & 7 & 2 \\
Karak & 4 & 3 & 1 \\
Tafeeleh & 2 & 2 & 1 \\
Maan & 3 & 2 & 1
\end{tabular}

Source: MOA, 2012.

\subsection{Data Collection}

To obtain information from respondents, a structured questionnaire was designed. Total variable and fixed costs, total revenues, net income were the core of the collected data. The study covered the period March 2012 to August 2012. Secondary data sources include Department of Statistics, the Ministry of Agriculture sources, and other agricultural related agencies.

\subsection{Data Analysis}

Averages costs and revenues of the thirty mills were calculated to accomplish the required analysis. The financial indicators (NPV, IRR, and B/C ratio) for the investigated enterprises were calculated. The NPV was calculated as follows:

$$
\mathrm{NPV}=\mathrm{Ri} \div(1+\mathrm{i})^{\mathrm{t}}
$$

Where, t: time, i: discount rate, and Ri: net cash flow.

The IRR can be mathematically calculated as follows:

$$
\mathrm{CF}_{0}+\frac{C F_{1}}{(1+r)^{1}}+\frac{C F_{2}}{(1+r)^{2}}+\frac{C F_{3}}{(1+r)^{3}}+\frac{C F_{z}}{(1+r)^{z}}=0
$$

Where CF: cash flow in the last period being $\mathrm{n}$, and $\mathrm{r}$ is the internal rate of return to be calculated.

The ratio of total value of benefits to the total value of the costs is the $\mathrm{B} / \mathrm{C}$ ratio. A reliable measurement to accept the investment is when $\mathrm{B} / \mathrm{C}$ ratio greater than or equal to one. $\mathrm{B} / \mathrm{C}$ ratio is the ratio of the benefits to costs of an enterprise expressed in monetary basis (Ascott, 2006).

The financial feasibility for enterprise was analyzed at a discount rate of $12 \%$ over a 10 years period. 


\section{Results and Discussion}

Average cash flows using average costs and average returns of the thirty mills were determined. The NPV, IRR, and $\mathrm{B} / \mathrm{C}$ were calculated. Tables 5 and 6 show yearly average costs and yearly average returns of the investigated mills respectively. Table 7 shows cash flows of the mills for a period of 10 years and Table 8 shows the calculated financial indicators respectively. The calculations made under the assumption that both costs and returns increase by $1 \%$ annually.

Table 5. Yearly average costs

\begin{tabular}{lc}
\hline Fixed Costs & JDs \\
\hline Land \& building & 107000 \\
Vehicles & 34000 \\
Machinery, olive, and Equipments & 318000 \\
Fresh and wastewater reservoirs & 13000 \\
Total & 472000 \\
Variable costs & JDs \\
Labor & 5000 \\
Water \& electricity & 5000 \\
Fuel & 3000 \\
Maintenance & 7000 \\
Cans (for olive oil) & 10000 \\
Taxes & 5000 \\
Miscellaneous & 3000 \\
Total & 38000 \\
\hline
\end{tabular}

Table 6. Yearly average returns

\begin{tabular}{lc}
\hline Item & Explanation \\
\hline Production & $30 \mathrm{kgs} / \mathrm{hr}$ \\
Operating hours & $24 \mathrm{hrs}$ \\
Operating period & $75 \mathrm{days}$ \\
Quantity produced & $54000 \mathrm{kgs}(30 \times 24 \times 75)$ \\
Price of olive oil & $4.5 \mathrm{JDs}$ \\
Return from selling olive oil & $243000 \mathrm{JDs}(54000 \times 4.5)$ \\
Return from selling dried olives & $10000 \mathrm{JDs}$ \\
Total returns & $253000 \mathrm{JDs}$ \\
\hline
\end{tabular}

Table 7. Cash flows of olive mills for a period of 10 years

\begin{tabular}{|c|c|c|c|c|c|}
\hline Year & Fixed Costs (JDs) & Variable Costs (JDs) & Total Costs (JDs) & Returns (JDs) & Cash flow (JDs) \\
\hline 1 & 472000 & 38000 & 510000 & 253000 & -257000 \\
\hline 2 & & 38380 & 38380 & 255530 & 217150 \\
\hline 3 & & 38763.8 & 38763.8 & 258085.3 & 219321.5 \\
\hline 4 & & 39151.4 & 39151.4 & 260666.2 & 221514.8 \\
\hline 5 & & 39542.9 & 39542.9 & 263272.9 & 223730 \\
\hline 6 & & 39938.3 & 39938.3 & 265905.6 & 225967.3 \\
\hline 7 & & 40337.7 & 40337.7 & 268564.7 & 228227 \\
\hline 8 & & 40741.1 & 40741.1 & 271250.3 & 230509.2 \\
\hline 9 & & 41148.5 & 41148.5 & 273962.8 & 232814.3 \\
\hline 10 & & 41560 & 41560 & 276702.4 & 235142.4 \\
\hline
\end{tabular}


Table 8. Financial indicators of olive mills

\begin{tabular}{lc}
\hline Indicator & Value \\
\hline NPV (JDs) & 837966.05 \\
IRR (\%) & 85 \\
B/ C Ratio & 2.3 \\
\hline
\end{tabular}

Table 8 shows that the NPV for this enterprise was positive and acceptable (837966 JDs). The IRR value for this enterprise was $85 \%$, indicating that each money unit invested in this enterprise will provide returns higher with about $85 \%$ than the costs paid. The $\mathrm{B} / \mathrm{C}$ ratio was higher than one. It was 2.3 indicating that this enterprise is viable. The benefits outweighed the actual costs that went in the enterprise.

\section{Conclusions}

The results of this study revealed that olive mills can be a viable encouraging, and profitable enterprise because of its capability to generate a NPV of 837966 JDs which is highly positive and acceptable. The IRR and B/c ratio values for this enterprise were also economically accepted. Since the benefits of olive mills outweighed the actual costs that went in the enterprise it is advised to adopt such enterprise in Jordan. The computed financial indicators for this enterprise confirm this advise.

\section{Acknowledgments}

The author wish to express his deep sense of gratitude to the Jordanian Ministry of Agriculture staff and the Agricultural Directorates staff in the whole country. The author would also like to convey thanks to the Faculty of Agriculture / Jerash University.

\section{References}

Al-Shdiefat, S., El-Habbab, M. S., \& Al-Sha'er, A. (2007). Introducing Organic Farming System in Olive Production and Linking Small Farmers to Markets: “A Success Story”. Project of High Quality Organic Olive Oil for Exports. The Global Partnership Program (GPP) Publications. Amman, Jordan. Retrieved from http://www.aarinena.org/documents/SuccessStories/Jordan.pdf

Ascott, E. (2006). Benefit cost analysis of wonder world drive overpass in San Marcos, Texas. Applied Research Project. Texas State University. Retrieved from https://digital.library.txstate.edu/handle/10877/3783

Baker, S. L. (2000). Perils of the internal rate of return. Retrieved from http://hspm.sph.sc.edu/COURSES/ECON/invest/invest.html

Bent, F., Mette, K., Holm, S., \& Buhl, S. L. (2002). Underestimating costs in public works projects: Error or lie? J. Am. Plann. Assoc., 68, 279-295. http:dx.doi.org/10.1080/01944360208976273

Boardman, A. E., Greenberg, D. H., Vining, A. R., \& Weimer, D. L. (2001). Cost-Benefit Analysis: Concepts and Practice (2nd ed.). New Jersey, USA: Prentice Hall.

Bruce, J. F. (2003). Investment Performance Measurement. New York, USA: Wiley.

Lin, G. C., Nagalingam, I., \& Sev, V. (2000). CIM Justification and Optimization. London, UK: Taylor and Francis.

Ministry of Agriculture (MOA). (2012). Statistics Book. Jordan.

Orth, K., Robinson, R., \& Hansen, W. (1998). Making more informed decisions in your watershed when dollars aren't enough. IWR Report 98-R-1, US Army Corps of Engineers, Alexandria, Virginia.

\section{Copyrights}

Copyright for this article is retained by the author(s), with first publication rights granted to the journal.

This is an open-access article distributed under the terms and conditions of the Creative Commons Attribution license (http://creativecommons.org/licenses/by/3.0/). 